\title{
Meša Selimovićin Ada Romanına Eleştirel Bir Bakış
}

\section{ÖĞR. GÖR. ESMA NUR ÇETINKAYA KARADAĞ*}

\section{Öz}

Yugoslav yazar Meša Selimović' in 1974 yılında yayımlanan romanı Ada, insanın kendiyle, diğer insanlarla, doğayla ve diğer canlı türleriyle etkileşimini merkeze alır. İki dünya savaşına şahitlik etmiş İvan ve Katarina Mariç, şehrin yaşlıları dışlayıcılı̆̆ı ve insanların şehirde birbirleriyle yakın ilişki kuramadığı bir mekâna dönüşmesiyle huzuru bulma umuduyla Adriyatik'te bir adaya yerleşirler. Geçmişin ağırlığı, yaşanamamış bir hayata özlem, insanın boşluk hissinden kurtulma ve dünyada bir iz bırakarak, varoluşuna anlam ve somutluk katma çabası romanın temalarıdır. Adayı hem gerçek hem de sembolik mekân olarak seçen Selimović romana sağlam bir zemin oluşturur. Bu çalışmanın birincil amacı, modern yaşamın insanı gelenekten ve geçmişten koparışını, insanı kendine, eşine, diğer insanlara ve tabiata yabancılaştırmasını göstermektir. İkincil olarak bu çalışmada, şehirde zaman ve mekân sıkışması, insanın artan yalnızlığı, varoluşsal sancıları ve mülkiyet hırsının insanları değiştirmesi gibi konuları sosyolojik, psikolojik ve ekolojik çıkarımlarla göstermeyi hedefliyorum.

Anahtar sözcükler: Meša Selimović, Ada, modern, yabancılaşma, şehir

\section{A CRITICAL LOOK TO MEŠA SELIMOVIĆ'S NOVEL ISLAND}

\section{Abstract}

The novel Island, published in 1974 by Yugoslavian author Meša Selimović, centers on human interaction with herself/himself, other people, nature and other living species. Ivan and Katarina Maric, who witnessed the two world wars, settle on an island in the Adriatic, hoping to find peace when the city turns into a place where the old people are excluded and people cannot communicate with each other. The themes of the novel are the burden of the past, yearning for an unlived life, human's struggle to free herself/himself from the feeling of emptiness, leave a mark on Earth, and add meaning and concreteness to her/his existence. Selimović, using the island as a setting both realistically and metaphorically, provides a stable base for the novel. This study primarily aims to show that modern life separates people from tradition and the past, alienates people from themselves, their spouses, other people and nature. Secondly, in this study, I aim to show the issues such as the compression of time and space in the city, human's increasing loneliness and her/his existential pains, and the greed for property that change people with sociological, psychological, and ecological implications.

Keywords: Meša Selimović, Island, modern, alienation, city

\footnotetext{
* Recep Tayyip Erdoğan Üniversitesi, esmanur.cetinkayakaradag@erdogan.edu.tr, orcid: 0000-0003-1940-7364 


\section{Gíriş}

$\mathrm{B}$ alkan coğrafyasının 20. Yüzyıldaki güçlü seslerinden Meša Selimović (1910-1982), 1966 yılında yayımlanan Derviş ve Ölüm romanının pek çok dile çevrilmesiyle edebiyat dünyasında saygın bir yer kazanmıştır. 1974 yılında, Yugoslav yönetmen Zdravko Velimirović tarafından ilk film adaptasyonu, 2001 yılında da Türk-İtalyan ortak yapımı şeklinde İtalyan yönetmen Alberto Rondalli tarafından ikinci film adaptasyonu yapılan eser sinematografik pek çok ödüle de layık görülmüştür. Uzun yıllar Selimović'in Türkçe okunan tek kitabı olan Derviş ve Ölüm, modern Yugoslav edebiyatının yapı taşlarından biri olarak incelenmiştir.

Selimović, Yugoslavya'da takdir gören bir yazar olmasına karşın, dünya edebiyat camiasında hak ettiği üne kavuşamamıştır, çünkü Yugoslav projesiyle örtüşmeyen sıkı bir muhalif değildir (Wachtel, 2006, s. 149). Müslüman bir aileden gelmesine rağmen kendini Sırp edebiyatı yazarı olarak tanımlayan Selimović, Bosna'nın çoklu kimliklerini özümseyerek yetişmiştir ve hem Sırplar hem de Boşnaklar tarafından sevilen nadir tarihi figürlerdendir (Hayden, 2007, s. 112). Selimović'in İngilizceye 1983 yılında çevrilen Ada romanı Türkçeye 2020 yılında kazandırılmıştır. İkinci Dünya Savaşı'ndan sonra yazdığı ve çoğunluğu savaş temasıyla harmanlanan iyilik, kötülük, suç ve özgürlük gibi temalarla işlediği hikâyelerden oluşan Kızıl Saçlı Kız Türkçe'ye ilk kez 2019'da yine savaşın kanlı yüzünü gösterdiği kısa romanı Sis ve Ay Işı̆̆ı Türkçe'ye 2020 yılında ve Selimović'in Belgrad'da vefatından önce tamamlayamadığı romanı Çember 2021 yılında Türkçe'ye çevrilmiştir. Selimović'in, 1970 yılında yayımlanan romanı Kale, Türkçe'ye 2001 yılında çevrilmiştir; ancak kitabın güncel basımı yoktur.

Bu çalışmanın amacı, Avrupa'nın savaş sonrası dönemde değişen çehresinin Yugoslavya bölgesine yansımasının naif bir aktarımı olan $A d a^{\prime}$ yı kendine ve evrene yabancılaşan modern, çalışkan, üretici ve tüketici insanın müreffeh bir hayat inşa ederken kaybettiği değerlerin ve samimi ilişkilerin özlemli bir hatırlatması olarak yorumlamaktır. On dokuz bölümden oluşan ve fragmental anlatıyla yazılan romanı bu çalışmada ilk alt başlı̆̆ı Varoluşsal Meseleler Bă̆lamında İnsan, ikinci alt başlı̆̆1 Modern Zamanlarda Yaşlanma, Yalnızlık ve Yabancılaşma ve üçüncü alt başlı̆̆1 Insanın Doğadaki Diğer Türlere Üstünlüğü sseklinde kurarak Derviş ve Ölüm gölgesinde kalan ancak başarılı bir modern zamanlar kritiği olan $A d a^{\prime}$ yı yorumlayarak literatüre katkıda bulunmayı hedefliyorum.

\section{VAROLUŞSAL MESELELER BAĞLAMINDA INSAN}

Ada romanının esas karakteri İvan Mariç, kendisi için daha farklı bir hayat hayal ederken, rastlantılar veya kader neticesinde dünyadaki çoğunluk gibi sıradan bir hayat sürmektedir. Tarihe geçmiş şahsiyetlere özenen İvan, onlar gibi olağanüstü işler başaramadığı için kendini küçümser.

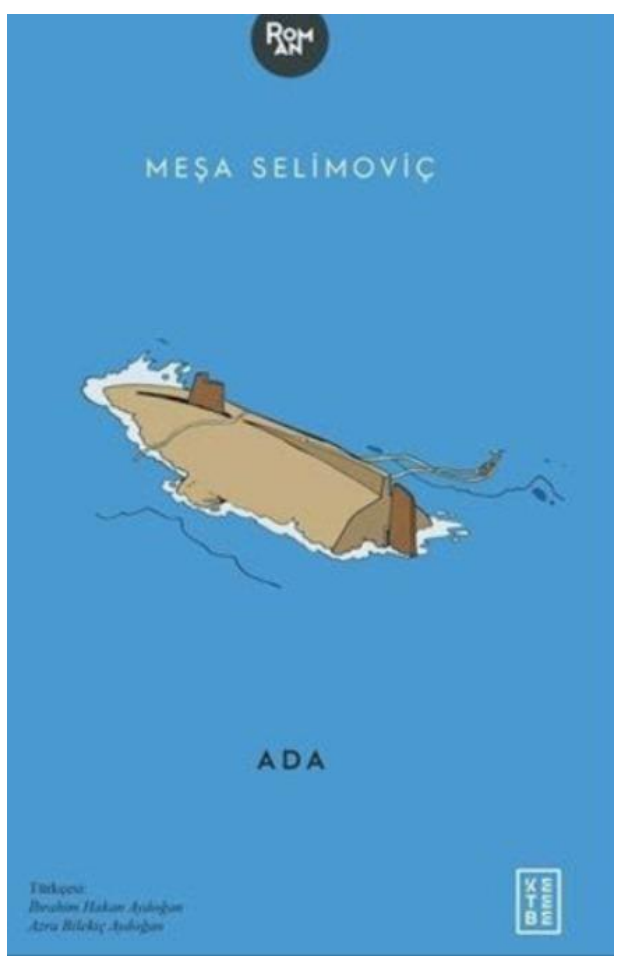


İvan aslında idealindeki benlik ve gerçekteki benliği arasındaki uçurumdan dolayı mutsuzdur. İvan, kendi mutsuzluğunu karısı Katarina'yı sık sık eleştirerek ona da yayar. Mesela Katarina'yı saçlarını boyadığı için eleştirir, çünkü ona göre saç boyamak ihtiyarlığ gizlemektir. Katarina ise kocasına, gençliğindeki gibi güzel görünmek için boyadığını söyler ve ilk tanıştıkları günü ona hatırlatır:

"Chopin çalıyordum; herkes gibi beni izliyor, dinliyordun. Hayran kalmıştın. Herkes hayran kalmıştı. İnsanların gözlerinin nasıl parladığını hâlâ görebiliyorum."

"Parlamaz olur mu, hiçbir şey değişmedi ki."

“Öldüler, neredeyse tamamı ölü."

"Her şey hatıralarımda kayıtlı."

"Hayaletleri mi seviyorsun?"

"Hayaletleri sevmekten değil. Olup biten şeyleri seviyorum." (Selimović, 2020, s. 7).

İvan'ın hatıralar, Katarina'nın ise hayaletler diye gördüğü şey geçmişin iki farklı insanda iki farklı tezahürüdür. Çünkü geçmişteki tüm olaylar ve duygular hafızalarımızda süresiz saklanır. Viktor Frankl, insanın yaşlandığında bu hatıralara seyahatini ya verimini kaybetmiş anız tarlası ya da tüm yaşanmışlı̆̆ı içeren içi dolu zahire ambarı benzetmeleriyle yapar (2019, s. 39). Üstteki alıntıda, Katarina geçmişe anız tarlası gibi bakar çünkü ona göre tüm hatıralar ölmüştür. İvan ise, olan şeyleri sevdiğini söyleyerek zahire ambarına odaklanır bu diyalogda. Hafızanın, insanın umut ve korkuları için önemli şeylerin bekçisi olduğunu belirten Rollo May, hafızanın modern saatin nicel göstergesinden ziyade deneyimlerimizin zaman içindeki nitel önemiyle şekillendiğini söyler (2021, s. 247). Gençken insanın geleceğe, yaşlandığında da geçmişe bakmasının bulunduğu anı gerçekten yaşayamamaktan kaynaklanır ve insan psikolojik ve olgusal hafızaya tutunarak hayatı göğüsler (Krishnamurti, 2013, s. 227-229). Katarina'nın ve İvan'ın aynı olayı bugün farklı değerlendirmesi psikolojik ve olgusal hafızalarının nitel farklılığından kaynaklanır. Karı-koca ilişkilerinde genellikle Katarina'ya hoyrat davranan İvan onun kalbini kırar:

“Neden bu kadar kötüsün sevgilim?"

“Çünkü acı çekiyorum."

"Fakat o zaman daha çok acı çekeceksin."

"Gideceğim buralardan."

"Nereye gideceksin?"

“Herhangi bir yere. Dünyanın neresi olursa." (Selimović, 2020, s. 11).

Frankl, 1stırabın kader ve ölüm gibi yaşamın tamamlayıcı parçası olduğunu ve ıstırap olmadan insanın yaşamının tam olmayacağını söyler. İnsan ancak bu ıstırabı cesaretle kabul ederse yaşamına anlam katabilir (2021, s. 78). İvan'ın acı çekiyor olması da varoluşsaldır ve bu ıstırabın ancak bulunduğu yerden gittiği zaman sona ereceğine inanır. Fakat bu gitme özlemini hiçbir zaman somutlaştırmaz. Bu gitme özlemi Heyecan adlı ikinci bölümde de karşımıza çıkar:

"Günün birinde gideceğim."

“Nereye?"

"Neresi olursa."

“Ne zaman?"

“Hiçbir zaman." (Selimović, 2020, s. 19). 
İvan'ın gündelik hayatı bir saatin sarkacı gibi gitme ve kalma seçenekleri arasında geçer, çünkü şu anda olduğu yerden memnun değildir ve bu memnuniyetsizliği mekâna bağlar. Ancak o mekândan ayrıldığında, neresi olduğunu bile bilmediği bir yere gittiğinde geçmişin peşini bırakacağına inanır. İvan, şimdiye kadar anlamlı bir hayat inşa edemediğini düşündüğü yerden kurtulup, başka yerde bambaşka bir hayat yaratma özlemindedir. İvan'ın onu ara ara yoklayan bu gitme isteği aslında yaşamındaki kısır döngüyü kırmak amacıyladır, çünkü buradaki ve şimdideki anlamsızlık onu esir etmiştir. Adam Phillips, yaşadığımız tecrübelerden ziyade yaşamadığımız tecrübelerle alakalı bilgi sahibiymiş gibi hayatımızı idame ettirdiğimizi, çünkü doğal düzeni bozabilmemizin ve gerçekten çıkıp gitmemizin zor olduğunu söyler (2019, s. 98-99). İvan da aslında gidemeyeceğini bilir ama gitme isteğini naifçe dile getirir, çünkü onun da umudu yaşamadığı bir hayatın şimdi ve burada olandan daha iyi olacağıdır. Katarina ise İvan'ın bu gitme isteğinin can sıkıntısından kaynaklandığını düşünür:

“Niçin bir şey yapmiyorsun?"

"Yapacak işim yok. Anlamlı ne iş var ki yapılacak?"

"Ne olursa."

"Amuda mı kalkayım?"

“Kimileri kalkıyor." (Selimović, 2020, s. 17).

Katarina, ev ve bahçe işleriyle meşguldür ve gününü eylemsel olarak dolu geçirir, ancak İvan iş hayatının temposundan emekliliğe geçmiştir ve eylemsiz bir hayata dair bilgisi yoktur. Tüm memuriyet görevlerinden artık azadedir, ancak görev odaklı olmayan sakin bir yaşamda salt kendisi için anlamlı bir eylem bulamaz. Bu nedenle karısının önerileri ona saçma gelir. Frankl, kurucusu olduğu logoterapik psikiyatri yaklaşımında, insanın anlamı farklı yollardan bulabileceğini söyler. Mesela insan üreterek, bir iş yaparak, yeni bir şey tecrübe ederek, biriyle yakınlaşarak ve acıya karşı aldığı cesur tutumla ıstırabın üstesinden gelebilir (2021, s. 116). İvan, anlam bulamadığı sıradan eylemlerle Katarina'nın vakit geçirebilmesine şaşırır. Hatta onun iskambil fallarıyla mutluluk ummasından dahi rahatsızdır.

İvan'ın beklentisiz ve karamsar ruh hali, Katarina'nın ise ne istediğine karar veremeden de olsa geleceğe dair mutluluk düşüncesinin olması karı kocayı ayırır. İvan, Tanrı inancı ya da fallarla mutluluğun gelmeyeceğinden emindir, çünkü hayat onları bu adaya sürüklemiştir. Mutluluk ise bu adanın dışında bir yerde kalmıştır. Katarina'nın kilisedeki ayine gitmesini de tuhaf bulan İvan, karısının hayatına anlam ve değer katmak için boşa çabaladığını düşünür. İvan, karısının kiliseye gitmesinden neden rahatsız olduğunu gerçekten bilmez ancak çevresine mutaassıp görünmek de istemez. Katarina ise huzursuzluğunun arttığı bir yaşamda kendine kurtuluş yolu açmaya çalışır. Yıllar sonra kiliseye gitmesi de bu kurtuluş umuduyladır. May, din kavramının insana güven duygusu vererek, insanın ahlaki bilinç düzeyini yükselttiğini ve şahsiyetini geliştirmesine katkıda bulunduğu takdirde kişi için yapıcı olabileceğini söyler. İnancı ya da dini insan için iyi veya kötü diye temellendirmektense kişinin inancından aldığı etik kuvvetini ne ölçüde kullanacağının onu güçlendirebileceğini de ekler (2021, s. 195). Katarina, kocasının talebiyle yıllar önce kiliseye gitmeyi bırakmıştır, ancak yaşlandığında ruhunu doyuracak hiçbir eyleminin olmadığını görerek şöyle haykırır: 
“Nasıl bir hayat benimkisi, sen söyle! Ama söylerken adil ol. Hayvandan beter oldu halim; Tanrım sen koru! Yemek yapıyorum, yiyorum, bulaşık yıkıyorum, tavukları besliyorum: hepsi bundan ibaret. Benim de bir canım var. Ruhum ne olacak?"

“Ama ruhun da kendine özel ihtiyaçları var. Sen akşamları içip sızdıktan sonra horlamaya başlayınca ben evin önüne çıkıp banka oturuyorum. Gökteki yıldızlara bakıp ağlıyorum. Ruhum boş." (Selimović, 2020, s. 27).

Katarina'nın aşkın bir ruh haliyle yakarışını yansıtan cümleleri onun anlamsızlık ve ruhundaki boşluktan kurtulmak için çabasının göstergesidir. Katarina, bu boşluğun farkına vararak ve onu eylemleriyle doldurmaya çalışarak aslında kendini tazelemek ister. Çünkü geçmişini ölü gören Katarina, geleceksiz kalmaktan çekindiği için şimdide kendini yeniden yaratmaya çalışır. İvan, karısının haklı isyanına gerekçe olarak hiçbir insanın ruhunun dolu olmadığını söyler. Ancak Katarina'yı saran bu boşluk duygusu canını acıtacak düzeydedir:

"Tanrım ben neden böyle bomboş yaşıyorum? Gündüz ve gece, sabah ve akşam geçiyor ama benim içimde hiçbir şey yok, bomboşum, tavuklardan farksızım. Ne acı."

“Tavuklar üzüntü nedir bilmez."

"Ben bilirim arkadaş. Acıyla bağırmamak için boğazımı sıkıyorum."

“Niye kadın, Tanrı aşkına, niye?"

"Ruhum 1ssız, kalbim boş."

"Kimin suçu bu?"

“Kimsenin. Belki benim şanssızlığımdan belki de hayatım böyle." (Selimović, 2020, s. 27-28).

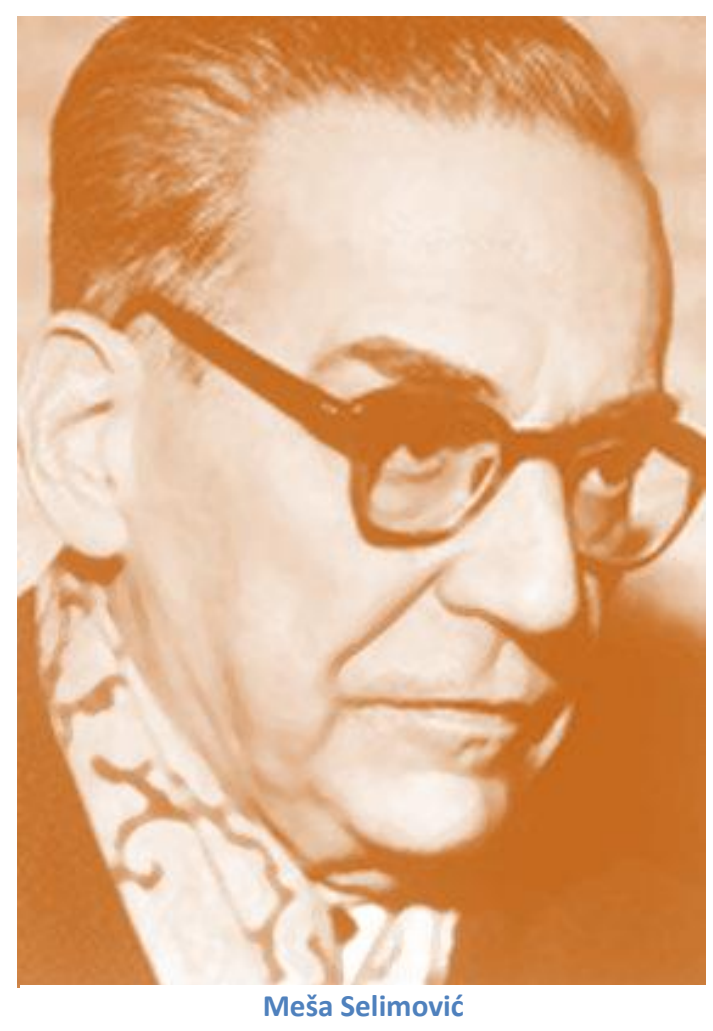

İvan'ın rasyonel akla sığınarak çözdüğü ya da üzerini örttüğü anlamsızlık ve boşluk hissinden Katarina kaçmaz. Paul Tillich, boşluğu insanda dışsal olaylar veya içerideki kargaşadan dolayı çöken inancın ürettiği bir kaygı olarak görür ve boşluk kaygısının insanı anlamsızlığa sürüklediğini söyler. Boşluk ve anlam kaybı da yokluğun ruhanî hayat üstündeki tehdidin gösterimleridir (2020, s. 70). Katarina'nın duygularını bastırarak bağırmamak için boğazını sıkması da patolojik bir durumdur, çünkü kadın kendine zarar verecek raddede tehdit altında hissetmektedir. Tillich'e benzer şekilde, Frankl da varoluşsal boşluğun yirminci yüzyıl insanının yaygın sorunlarından olduğunu ve bu boşluğun can sıkıntısı, anlam kaybı olarak günlük hayatta tezahür ettiğini söyler (2021, s. 112). Katarina ve İvan arasındaki diyalog şöyle devam eder:

"Tanrı manasızlık, korku ve yalnızlığa karşı sığınaktır."

“Tanrı palavra. Var olmadığını bildiğim şeye nasıl inanabilirim?"

“İnanmak istersem vardır. Ĕger varsa, en azından benim arzularımda varsa, yalan değil demektir."

“Niçin insanlığa ait bir şeye inanmıyorsun?" 
“İnsanlığa ait her şey yalan."

“Saçmalık! Artık bu kadarı da mantık dışı." (Selimović, 2020, s. 29).

Katarina'nın insanlığa inancını yitirmesi ve Tanrı'ya sığınması; İvan'ın da bu durumu mantıksız bulması tecrübe ettikleri varoluşsal meseleye farklı çözüm getirmelerindendir. Boşluk ve yalnızlık hislerinin birlikte ilerlediğini söyleyen May, önceki yüzyıllarda insanlığı bir arada tutan değer ve gayelerin modern çağda artık inandırıcılığını yitirdiğini ve insanın acılarından kurtulabilmesi için kendine yeni bir dayanak noktası yaratmaya çalıştığını yazar (2021, s. 55). Katarina'nın yıllar sonra kiliseye gitmesi de bu dayanak noktasını aramasındandır.

İvan, üstteki diyalogda, Katarina'nın acıyla yakınmasını mantıksız bulsa da kendi içini kemiren varoluşsal boşluğu da görmüştür. Ancak, bu boşlukla cesurca yüzleşmektense onu yok sayar, çünkü zaman onun tüm hayallerini ve aşklarını ezip geçmiştir. Geçmişin enkazıyla şimdi baş etmesi imkânsızdır. Ayrıca, İvan bu boşluğa ve anlamsızlık duygusuna kapıldıkça intihar etme ihtimalinin de farkındadır. İvan, tüm umutsuzluğuna rağmen bu yola başvurmayacağını kendine telkin eder:

Kalbin içi neyle dolacak ki? Onu gittikçe daha da ezen yıllar mı dolduracak? Suya düşmüş ümitler mi? Gönülsüzce katlandığı ve kurtulamadığı hapislik mi? Hayat yolunda gömlek değiştiren yılanların bıraktıkları boş deriler gibi kalan beyhude hayaller mi? Geriye külleri bile kalmayan aşk mı? Yalnızlık mı? Hayata manasız bir şekilde devam etmek mi? Hayır, kendisine cevaplanamaz sorular sormayacak, kendini öldürmeyecekti. Şimdiye kadar nasıl yaşadıysa öyle yaşayacaktı (Selimović, 2020, s. 30-31).

İvan, ömrü boyunca oluşturduğu dünyaya kendisini yabancılaştırmayacak ve geçmişe yönelik sorgulamalara girmeyecektir. Geçmiş ve şimdi arasında bir kopukluk oluşturursa ve bu sorularını artırırsa kendine zarar vermekten de korkar; çünkü içten içe o anlamsızlık ve boşluktan korkar. Engin Geçtan, kişinin günlük yaşamında diğer insanlar, nesneler, kurumlar, birbirleri ve tabii ki kendiyle yoğun ve tekrarlı bir ilişki yaşayarak bir yaşam alanı oluşturduğunu söyler. Bu yaşam alanının altında büyük bir boşluk vardır ve bu boşluktaki yaşantı tamamen ve sadece kişiye özeldir (2016, s. 157). İvan'ın kalbinde boşluk olarak hissettiği aslında, Geçtan'ın ifade ettiği yaşam alanının altındaki boşluğun uyarılmasıdır. Ayrıca İvan'ın yılanların deri değiştirmesi benzetmesi, modern hayatta sürekli 'bir başkası olmak' yarışındaki insanın tatmin olmadığı bir benlikten başka bir benliğe geçişinin ancak yaratıc yıkıcılık sayesinde olduğunu söyleyen Zygmunt Bauman'a götürür bizi (Bauman, 2019, s. 101). Ancak İvan böyle bir yaratıcı yıkım sürecine girmek için çok yaşlıdır, o nedenle kendine soru sormayacaktır.

İvan, ömrünü olağanüstü şeyler başarmış insanların portrelerine imrenerek geçirmişir. Kaderin onlara muazzam hikâyeler sunarken kendisine neden cimri davrandığını sorgular. Çoğunluk gibi yaşayıp ölecek olması, ardında hatırlanacak bir eser ya da anlatılacak bir kahramanlık hikâyesi bırakamayacak olması onu hep üzer. Dünyada olmasa da kendi çevresinde dahi etkin bir şahsiyet olamadığını görüp, kaçırdığı fırsatlardan yakınır. Mesela savaş esnasında kayınbiraderinin yönlendirmesiyle köy fırınında ekmek yapar. Ustaşalar'a katılmadığı için sonradan sürekli hayıflanan İvan'ın başına absürt bir olay da gelir. Alman devriyesinin bir baskında İvan'ı düşman zannedip esir etmesiyle İvan kendini esir kampında bulur: 
Biri topçu çavuşu diğeri de levazım subayı olmak üzere iki kardeşi daha vardı ve bunlar kısa Nisan Savaşı'na katılmış, ikisi de evlerine dönmüştü. Askeri üniformalarını bir yerlere saklamışlar ve sivil olarak iş bulmuşlardı. Bir tek kendisi çürük raporu sahibi bir sivildi ama işte kendisini Almanya'da esir kampında bulan da bir tek kendisiydi. Fırıncılık zanaatı ve o aptal çakışır asker pantolonu yüzünden (Selimović, 2020, s.101-102).

İvan, esir kampında kaldığı dört yıl boyunca kaderin kendiyle dalga geçtiğini düşünür. Yugoslavya'ya döndüğü zaman başından geçenleri anlatınca da komik duruma düşer. Devrime katılmadan faşizm kurbanı olan İvan, yaşamını sinek gibi, iz bırakmadan geçirdiğini görür. Ante Pavelić (1889-1959) tarafından kurulan ve Hırvat Devrimci Hareketi olarak bilinen Ustaşalar, Hırvatistan'ın Yugoslavya'dan ayrılarak bağımsız bir devlet olma idealini savunmuşlardır ve 1929-1945 yılları arasında faaldir. Ustaşalar, İvan'ın özendiği bir yapı olsa da idealine ulaşmak için Boşnak, Sırp, Yahudi ve Çingene halklara katliamlar yapmıştır (Encyclopedia Britannica, b.t).

Başka şahsiyetlerin ve hayatların görkemi karşısında zaman zaman kıskançlık duyan İvan, bir yürüyüşünde gördüğü taşa kazınan 'Nasılsın?' sorusundan çok etkilenir. İvan'a göre bu basit soru oradan tesadüfen geçen biri için çok değerlidir. Çünkü tam da karamsar düşüncelere gark olmuşken, gördüğü bu samimi soru İvan'ın yüreğini 1sıtır. Taşa kazınan bu sorudan ilhamla Katarina'ya bu dünyaya basit de olsa bir anıt dikmeleri gerektiğini söyler. Karısı parayı kiliseye bağış yapmayı önerir, ancak İvan'a göre kilise için para harcamak gereksizdir, çünkü kilise ölümü kutsar. İvan ise hayatı kutsamak ister. Hayalindeki anıt için para biriktirmeye başlayan İvan, bu sürecin yorucu ve uzun olmasından sıkılır; zaten evdeki diğer maddi gereksinimler onu demoralize eder. Biriktirdikleri parayı sıradan ihtiyaçlara harcarlar ve bu hayali de gerçekleşmez. Çünkü İvan, yaşamını anıt gibi sürdüremediği için, sona yaklaştıkça aslında gerçekten yaşayamamış olduğunu fark eder ve dünyaya somut bir eser bırakma telaşına girer. Frankl, her insanın yaşamının anıt olduğunu söylerken insan yaşamının hem geçici hem de kalıcı özelliğinin zıtlığına dikkat çeker. Çünkü ona göre insan yaşamının tamamı, yarattığı her şey, tüm eylemler, tecrübeler, sevgiler ve acılar sonsuzluk defterine yazılır ve asla kaybolmaz; bu sonsuzluk da insanın anıtıdır (2019, s. 109). İvan, yaşamının bütününü böyle değerlendiremediği için somut bir anıta muhtaçtır, oysa kendi yaşamı kendi anıtıdır.

\section{MODERN ZAMANLARDA YAŞLANMA, YALNIZLIK VE YABANCILAŞMA}

İki Zaman Arasında adlı bölümde İvan, annesinin ölümünden önceki son zamanlarını hatırlar. Mental sağlığını kaybeden yaşı kadın kendisini yedi yaşında bir kız çocuğu zanneder ve etrafındaki kişileri küçük bir çocuğun arzu ve beklentileriyle bıktırır. Psikolojik regresyona uğrayan kadın en yakınındaki kişiler tarafından dışlanır. Yaşlılığın korkunç yüzünü gören İvan ve Katarina yaşlı kadının yarattığı sıkıntılardan mustariptir. Nihayet kadın öldüğünde de bu ağır yükten kurtulmuş olmanın verdiği rahatlamayla sevinçlerini gizleyemezler, ancak cenazeye kimsenin katılmamasına kederlenirler:

“Cenazede kimse yoktu." dedi kadın.

"Sadece dilenciler vardı."

"Bir de ikimiz."

“Peki niçin öyleydi, sevgilim?” 
"Burası büyük şehir, sevgilim."

"Büyük şehir korkunç bir yer."

"İnsanlar yalnız yaşıyor."

“Ve yalnız ölüyorlar." (Selimović, 2020, s. 114).

Ölümü, modern yaşamın Ötekisi olarak gören Bauman, ölmek üzere olan kişiyle etrafındaki sağlıklı insanların iletişim kuramadığını çünkü hayatta kalanların diliyle ölmek üzere olanın dilinin farklı olduğunu yazar (2018a, s. 181). Nitekim yaşlı kadının ölmesi kalanlara bir rahatlama verir. Ancak bu ölüm şehirde yalnız oldukları gerçeğini de yüzlerine çarpar:

Şehirde sadece İvan'ın iş arkadaşlarını tanıyor olduklarını ancak şimdi fark etmişlerdi. Yaşadıkları büyük binadaki komşularını bile tanımadıklarını fark ettiler. Yıllardır sadece simaen tanışıyorlar, başlarını sallayarak selamlaşıyorlar ve birbirlerinin mutluluklarından ve hastalıklarından haberdar olmuyorlardı. Kimse kimseye herhangi bir şekilde yardım talebiyle gelmiyor, kimse kimseye şikâyetini anlatmıyor, kimse kimseyle mutluluğunu paylaşmıyordu. Sahip oldukları tüm arkadaşlarının şehirde değil, savaştan önce yaşadıkları banliyöden olduğunu fark ettiler (Selimović, 2020, s. 115).

Uygar kayıtsızlık olarak kavramsallaştırılan şehirdeki kamusal hayat yakınlık veya samimiyet üzerine temellenmez. Ortak mekânı kısa bir süreliğine paylaşmak zorunda kalan bireyler baş selamı veya hafif bir tebessümle karşıdaki insana güven vererek ve ondan da güven duyulmasını bekleyerek ilişkiler inşa eder (Goffman, 2021, s. 25). Apartmandaki simaen tanışma ve selamlaşma ritüelleri de bu uygar kayıtsızlığa örnektir. İvan ve Katarina, adaya göçtükten sonra, şehirdeki çocuklarını zaman zaman ziyaret etseler de şehirdeki misafirlik halleri onları zorlar. Şehir ve ada arasındaki somut mesafe adeta ebeveynler ve evlatları arasında gözle görülmeyen bir mesafeye dönüşmüştür.

"Senin de gitmemen lazımdı."

"Belki de haklısın."

"Bir dahaki sefere gitmene izin vermeyeceğim."

"Neden bizim gelmemizden hoşlanmıyorlar?"

"Benim gelmemden hoşlanıyorlar."

"Geçen sene de çabuk döndün. Tıpkı şimdi benim yaptığım gibi. Kaçıp geldin."

"Hissiz bakıyorlar. Öfkeli bakıyorlar. Yerimiz yok diyorlar. Zamanımız yok diyorlar."

"Biz buraya gelmek üzere yola çıkınca seviniyorlar."

"Orası ada size iyi gelir diyorlar." (Selimović, 2020, s. 9).

Çocuklar ve yaşlı çift arasındaki uzaklı̆̆ı okuduğumuz bu diyalog şehirdeki zaman ve mekân sıkışmasının göstergesidir. Geçtan, insanlığın geçirdiği hızlı dönüşümler neticesinde çıkan temel çatışmaların artık daha çetrefilli olduğunu, şehirlerde yaşayan insanların coğrafyadan mahrum kalmışçasına kendilerini iç mekâna hapsettiklerini söyler. Çünkü insanlar şehir yaşamında kendilerine üst-sistemlerin dayattığı işleri ve görevleri tamamlamak zorundalardır. Şehirde birer projeye dönüşen insanlar olmaktan yapmaya evirildiklerinden sürekli bir kayg1 halinde ya da diken üstünde yaşarlar (2018, s. 20). Giddens, modern hayatın mahremiyete artan ilgisi neticesinde ilişkilerin de değiştiğini ve ebeveyn-çocuk arasındaki ya da yakın akrabalıkla bağlantılı ilişkilerin geleneksel sorumluluklarından kurtularak zayıfladığını, geriye sadece adının kaldığını veya mahremiyetin sağlanmasıyla bu tür ilişkilerin yeniden biçimlendirildiğini söyler 
(2019, s. 136). İvan ve Katarina'nın artık yetişkin olan çocuklarının mahrem alanlarında istenmemesinin temelinde yeni bir form alan ebeveyn-çocuk ilişkisi ve şehir yaşamının onlara getirdiği kaygı ve nevroz vardır. Ayrıca çocukları tarafından adada yaşamaları tavsiye edilen çiftin durumu biyo-politik söylemle de değerlendirilebilir. Çünkü gençlerin yaşlılar için daha iyi olana karar verdiği toplumsal düzende yaşlıların görünmez olması gerekmektedir. Adanın, İvan ve Katarina'ya iyi gelmesi, onların adada denetimli tutulabileceğinden kaynaklanır. Ada bir nevi yaşlilar için sürgün yeridir ve bu sürgünü herkes için daha makul yapan şey de ada hayatının yaşlılara iyi gelmesidir. Selimović' in kitabın bu bölümüne Sürgün adını vermesi de manidardır:

"Birbirimize ihtiyacımız var. İkimizin de. Başka kimsemiz yok."

"Biz bile birbirimizin kimsesi değiliz ki"

"Öyleymişiz gibi düşüneceğiz."

"Zaten öyle düşünmeliyiz."

"Tabii ki öyle."

"Çocuklarımız da iyi insanlar."

"Belki iyi değiller ama bizi seviyorlar."

"Seviyorlar tabii, sadece zamanları yok."

"Yerleri de yok. Yerleri dar. Giderek daha daralıyor." (Selimović, 2020, s. 10).

Tüm bu yalnızlığın ortasında yaşlı çiftin fark ettiği şey birbirlerine muhtaç olduklarıdır. Çünkü mekân darlığının olduğu bir dünyada, varlıkların işgal ettikleri yeri boşaltmaları gerekir (Bauman, 2018a, s. 238). Yani, gençlerin yaşlı çiftten beklediği şey ölmeleri olmasa da gözden kaybolmalarıdır. Ayrıca yaşlıların şehirde istenmeyen varlığı sosyal eşitsizliği de gündeme getirir, çünkü modern şehirlerin tasarımı engelli ve yaşlıların özel ihtiyaçları ihmal edilerek yapıldığından, şehir hakkına eşit ulaşım sağlanamaz. Aktif yaşlanmanın mümkün olmadığı bir kent ortamı da yaşlıları duygusal yatırımlarının olduğu mekândan ayrılmaya zorlayabilir (İnalhan, 2020, s. 160-161). Batı kültürünün yaygın değerleri gençlik, bireycilik ve aktifliktir ve yaşlanan bireyin bu paradigmalara yetişmesi mümkün değildir. $\mathrm{Bu}$ nedenle moderniteyle birlikte yaşlanmanın tıp literatüründe hastalık addedilmesi yaşlıların toplumda damgalanmasına yol açar (Turner, 2017, s. 148-149). İvan ve Katarina da şehir yaşamının hızına yetişemezler ve hem çocuklarının yönlendirmesiyle hem de kendi istekleriyle adaya taşınırlar. Şehrin sahipleri gençlerdir ve yaşlıların yabancılıkları gün yüzüne çıkmıştır. Kapitalist modernleşmenin toplumsal hayatta tempo artışına ve hızlanmaya dayalı olduğu sistemde çalışanların payına düşen şey de elbette zamansızlık ve mekânsızlıktır (Harvey, 2019, s. 259). Ayrıca zaman emekle yabancılaştırılmış ve köleleştirilmişse insan zamanının olmadığını sanar ama zaman kavramı modern hayattan baskı unsuru olarak kaldırılırsa insan zamanının olduğunu görür (Baudrillard, 2018, s. 195). İvan ve Katarina'nın çocuklarının zamansızlıktan yakınması bu baskıyı hissetmelerindendir.

Apartmandaki bir kadının ölümü trajikomik şekilde duyulur. Apartmana dadanan bir hırsız, İvan ve Katarina'nın üst kat komşularının zilini günlerce çalar ve kadının seyahatte olduğuna hükmedip dairesine girer. Ancak evde kadının cesedini görünce daireden hiçbir şey çalmaz ve durumu polise ihbar eder. Katarina, komşusunun ölümünden sonra suçluluk duyar, çünkü günler öncesinden kendine yaptığı kahve davetini o zaman kabul etseydi, aralarında bir 
yakınlık doğacak veya dost olacaklardı. Kaçan bir dostluk fırsatının ardından kadının yalnız ölmesi Katarina'ya ve tüm apartman sakinlerine birbirlerini tanıması için fırsat verir. Ancak kısa süre sonra şehir temposu insanları tekrar girdabına çeker:

Binadaki herkes rahatsız olmuş, kendilerini kısmen suçlu görmüş birbirlerini daha sık görmeye başlamış ve böyle devam eden birkaç gün sonra her şey eskiye dönmüş; ofis, toplantı, televizyon, uyku ve hepsi yine telaşla yaşanmaya başlamıştı. Arada sırada meyhaneye, geçmişin o işlevini yitirmiş müessesesine zaman kalıyor, diğer her şey son anda yetiştiriliyordu (Selimović, 2020, s. 119).

Neoliberal ahlakın, mülkiyet hırsıyla beslenen aşırı bireyciliğe dayandığı günümüz modern dünyasında insanlığın arzularına göre yapılar ve yaşam alanları oluşturduğunu ancak tüm bu mükemmel binalara rağmen, şehrin tam kalbinde insanların bireysel yalıtılma, endişe ve nevrozla baş başa kaldığını söyleyen David Harvey, sistemin çatlaklarına işaret eder (2015, s. 56). Ölümlülüğün dehşetini apartmana getiren bu sessiz ölüm, apartman sakinlerini bir süre yakınlaştırsa da ölünün soğuyan bedeni gibi ilişkiler de bir süre sonra yine eski soğukluğuna döner. Çünkü insanları ilk başta bir araya getiren şey günün birinde aynı yalnız ölümle kendilerinin de karşılaşma ihtimalidir. Bu nedenle bu dehşetli yalnızlıktan kaçmak için kendilerini Ötekine, yani komşularına açarak kısa süreliğine de olsa iyi olma şansını yakalarlar (Bauman, 2018b, s. 102) Sonlarının komşuları gibi olmasından korkan, yabancılık ve yalnızlık kaygısından bunalan İvan ve Katarina daha yakın ilişki bulabilecekleri ümidiyle, şehirdeki evlerini oğullarına bırakarak bir adaya taşınır. Ancak özlemini çektikleri insani yakınlığı ve birlikteliği adada da bulamazlar:

İnsanlarla münasebet açısından şehirde ve köyde yaşam arasında büyük bir fark göremediler. Hem orada hem de burada insanlar kendileri için yaşıyordu ya da onlar, başkalarına nasıl yaklaşacaklarını bilmiyorlardı. Sanki geçmişle gelecek arasında, mevcut olmayan bir zaman diliminde yaşıyorlardı. Herkesin cebren bir araya geldiği ataerkil cemiyetin kişiliksiz homojenliğinin sıcaklığı ve herkesin kaçınılmaz surette tek başına yaşadığı modern yabancılaşmanın soğukluğu arasında (Selimović, 2020, s. 121).

Solgun Kadın adlı on üçüncü bölümde Katarina'nın zengin komşularının hayatına dair öğrendiği sırlarla şaşkına döndüğünü görürüz. Çünkü Katarina, mutsuzluklarının geçim sıkıntısından kaynaklandığına inanmaktadır ve lüks bir yaşamı olan kişilerin mutsuzluktan azade olduklarına inanır:

$\mathrm{Bu}$ zenginler nasıl yaşıyorlar? Her gün böyle mal mülkleriyle çevriliyken neler hissediyorlar? Canları hiçbir şey istemezken ne hakkında konuşuyorlar? Zenginlikleri onlara fakirlerin hayal dahi edemedikleri mutluluğu getiriyor mu? Belki de bu refah onlara insanın ruhunu sonuna kadar doyuran, insanı daha aziz ve cömert kılan ve kıskançlık, nefret veya çirkin arzular hissetmesine engel olan ve kendisini hayatın bataklıklarında kirletmesine izin vermeyen hususi bir mutluluk getiriyordur (Selimović, 2020, s. 125).

Katarina, kendi sıradan yaşamlarını zengin komşuları ve akrabalarınınkiyle kıyasladığında, zenginlerin mutluluk içinde yüzdüğünü düşünür. Çünkü varlık, statü ve iktidarın mutluluk sembolü olarak görüldüğü kültürlerde, zengin insanların daha yaşanmaya değer bir hayatları olduğu ve maddi imkânların artmasının insanları daha mutlu edeceği inancı aslında bir 
yanılsamadır. Ayrıca bu sembollerin içindeki kırklı ve ellili yaşlarda huzursuzluğuna çözüm arayan insanların psikiyatristlere akın etmesi de bir paradokstur (Csikzentmihalyi, 2020, s. 76). Nitekim Katarina, eczacı Rujiç'in karısının aslında çok mutsuz olduğunu, çünkü kocasını sevmediğini öğrenince Rujiç ailesinin gösterişli yaşamının gerçekte öyle olmadığını öğrenir. Topluma örnek evlilik diye sunulan şey aslında karı kocanın itibar kaybına uğramamak için katlandıkları bir beraberliktir. Bay Rujiç, karısının başka bir adamı sevdiğini bilmesine rağmen sıkı dinî inançlarından ötürü evliliğini sürdürür ve karısından toplum önünde mutlu görünmesini ister.

Bay Rujiç'in düzen ve kural temelli iş ve hayat anlayışı vardır. Bu anlamda, İvan ve Katarina'nın ölen oğullarının karısına benzer. Diyetine, uykusuna ve sporuna sıkı sıkıya bağlı, cinselliği hazdan arınmış Bay Rujiç, programlı ve düzenli hayat sürerek kendini adeta bir robot gibi programlamıştır. Bedenin tartışmasız özel mülk haline geldiği ve bakımının bireye ait olduğu normlar silsilesinde, kişi bedeninin sahibi olarak kontrolü elden bırakmamalıdır (Bauman, 2018b, s. 165). Bay Rujiç de ölçülü ve hesap edilebilir hayat tarzını kendine koruyucu bir kalkan yapmiştır.

İvan ve Katarina, büyük oğullarının evliliğinin tuhaf olduğunu düşünür, çünkü gelin ve oğulları arasında fikir birliği yoktur, sözleşmeye bağlı kalmaya çalışan iki insanın zoraki beraberliği gibi görünmektedir bu evlilik. Genç kadın ve adam bilinçsel olarak farklıdır. Kadın, sürekli çalışan, sosyalleşmeyen, arkadaş buluşmalarını ahmakça ve vakit kaybettiren aktiviteler olarak gören, evlilik içi cinselliği dahi aşağılayan, cinselliğin hayvani dürtülerine teslim olmuş zayıf bir insan karakterine ait olduğunu düşünmektedir. Frankl, bireyin şahsi yaşamıyla bütünlük arz etmeyen cinsel yaşamı varoluşsal engellenmenin sonucu olarak görür ve sevgiden ari cinselliğin imkânsız olduğunu israrla söyler (2019, s. 82). Eros'un Anteros'a dönüşmesi, cinselliğin rasyonel bir edim şeklinde kurallara uygun ve mistisizmden arınmış hali modern çağın cinselliği zevk ve mutluluk bahanesi olarak değil de baskı, şiddet, eşitsizlik, suiistimal ve enfeksiyon kaynağı olarak olumsuzlamasında yatar (Bauman, 2019, s. 60). Karı ve koca arasında boşluğu oluşturan şey ruhsal ve bedensel soğukluktur. Adamın kendisini aldatmasını da normal karşılayan kadın ondan bir tercih yapmasını ister ya evli kalacaklar ya da boşanacaklardır. Adam, duyduğu suçlulukla karsına döner; ancak bu defa da aralarına derin bir sessizlik girer. Aynı çatı altında bir düşman gibi yaşayan çift, soğukluğa ve sessizliğe de alışır:

Adam, kendini bu öldürücü suskunluktan kurtarmak için saatlerce, günlerce, yıllarca kendi koltuğunda bir gazete yığını ile oturur, son sayfalarını, spor bölümünü okur, bulmacalarda dururdu. Ya da TV programının başlamasını bekler ve reklamlardan haberlere, bilgi yarışmaları, filmler ve spor yayınları dâhil her şeyi izlerdi (Selimović, 2020, s. 46).

Evliliklerine rağmen ortak bir hayat süremeyen bu çift modern zamanlarda bireylerin evliliklerinde yaşadığı yalnızlığa örnektir. Katılımcısı olamadıkları bir hayatı ekrandan izlerler. Televizyon insani iletişimin ve sosyalleşmenin yerini alan robot rolüyle onların hayatını ekrandan yönetir. Kumanda her ne kadar insanın elinde dursa da ekrandan eve sızan türlü hikâyeler insanın kendi hikâyesini kurmasına engeldir. Ailede ve evde olması beklenen sıcaklık ve samimiyet, ekranın soğukluğuna teslim edilir. Evlerimiz artık yumuşacık mahremiyet adaları, aşkın ve 
arkadaşlığın paylaşıldığı güvenli adalar değil, akışkan modern çağımızda aile üyelerinin ayrı ayrı ama yan yana yaşayabildikleri bölgesel çarpışma alanları ya da eğlence merkezleridir (Bauman, 2019, s. 90-91). Krishnamurti, aynı evde iki insan arasında gerçek bir ilişki varsa sevginin de var olduğunu o zaman da aile içi tecrit, görev veya sorumluluğun kalmadığını söyler. Ancak samimi paylaşımların olmadığı aile ortamlarında ailenin tatmin aracı olarak kullanıldığını ve günümüz ilişkilerinin sevgiden yoksun ama tatmin arayışında şekillendiğini yazar (2013, s. 196-197). Bir gün adam karısına konuşmaları gerektiğini söyler, ancak kadın her zamanki soğukluğu ve günlük hayattaki aceleci eylemlerinden ötürü günlerce erteler. Ancak adamın istediği şeyi söyleyemeden bir trafik kazasında ölmesi kadını bu defa büyük bir pişmanlığa sürükler. Sevmediği kocasının yıllarca yasını tutar ve onu dinlemediği şeyin ne olabileceğine dair sürekli hayaller kurar. Kız kardeşinin sonradan uydurulan aşka ve anlamsız kedere tepkisi şöyledir:

“İki yabancı gibi yaşadınız. Öyle aşk mı olur? Asla birbirinize herhangi bir şey söyleme ihtiyacı duymadınız. Aşka değil nefrete benziyordu."

“Gerektiği kadar konuşuyorduk." (Selimović, 2020, s. 48).

Kız kardeşinin bu yorumu kadın için sarsıcıdır; ancak gerçekte de kendine yanılsama bir aşk yaratmıştır. Kocasının ölümünden sonra salt kendi imgelem dünyasında yarattığı bu aşka âşık olur. Kocasının varlığında ortaya çıkmayan bu aşk, onun yokluğunda yani kadının tek başına kontrol edebileceği bir forma dönüştüğünde onun için değerlidir. Oysa kadının ilişkisizlikten yarattığı ilişki kendi yalnızlığına tuttuğu aynadır. Kocasının ölümüyle esas yalnızlığı ve dünyaya yabancılı̆̆ı gün yüzüne çıkmıştır.

Yaşlı Mandarin Ölmeli mi? adlı on dördüncü bölümde, İvan ve Katarina'nın, adaya onları ziyarete gelen sosyoloji öğrenimi gören yeğenleriyle yakınlık kurmaları anlatılır. Daha önce hiç haberleri bile olmayan yeğenlerini tanımaktan memnun olan İvan ve Katarina bu beklenmedik ziyaretle yıllar sonra kalplerinde bir sıcaklık hissederler. Gencin konuşmaları onları çok etkiler:

Bugün hiçbir şeyin gerçek değerini bilmeden, eşyaya hizmet ediyoruz. İnsanların birer kalkan gibi kullandıkları ve bizleri umutla besleyen kelimeler değersizleştirildi. Kutsal kabul ettiğimiz kelimeleri öldürdüler, onların namusunu kirlettiler ve insanları ayakları altında ezerken bu kelimeleri bayraklaştırdılar. Artık kardeşlik, barış, dayanışma, mutluluk, eşitlik, aşk ve hürriyet kelimelerini kullanabilir miyiz? Onları elimizden aldılar. Başka taburun eline geçtiler. Bizi ilgilendiren biricik dünyada şiddetin sembolleri haline geldiler. Başka bir dünyamız da yok. Yeni kelimeler bulmak gerekiyor fakat nasıl yapacağımızı bilmiyoruz, o kelimelerin hangi kelimeler olduğunu bilmiyoruz. Ya da antik kelimeleri tekrar hatırlamamız gerekiyor: toprak, halk, yaşamak gibi. Belki de susmak. Ve belki, çığlık, hiç kimsenin duyamayacağı, çünkü artık kimse kimseyi ne duyuyor ne de anlıyor, fakat bu çı̆̆lık bizim için önemli, çünkü gürültülü makineler, agresif saçmalıklar, hidrojen bombaları ve ideolojik yaylım ateşlerinin dünyasında yapılabilecek tek şey bu: çığlık atmak (Selimović, 2020, s. 143-144).

Yitirilen bir dünyaya ağıt niteliğindeki bu cümleler, insanlığın son yüzyılda içinden çıkamadığı sorunları da barındırır. Kelimelerin değişmesiyle insanlığın değiştiği, piyasada alınıp satılamayan, meta değeri olmayan bir şeyin de değersizliğinin sistem tarafından dayatıldığı bir dünyada insanın sesi de çıkamaz. Ancak insan sıkışıp kaldığı bu dünyada susmak ve çığlık atmak arasında gidip gelir. Makinelerin ağır sanayi ve modern dünyanın yakıtı sanayileşmeyi temsil 
ettiği bu alıntıda; hidrojen bombaları düşmanların imha edilmesinin kolaylığını, ideolojik gerilimlerin de dünyayı belli normlar ekseninde kutuplaştırıp, biz ve onlar gibi tehlikeli ikili zıtlıklar yaratmasına referanstır. İnsanın, bu gerilimleri azaltmak gibi bir şansı yoktur; yapabileceği tek şey tüm bunlar karşısında isyan çığlığı atmaktır.

\section{INNSANIN DOĞADAKİ DİĞER TÜRLERE ÜSTÜNLÜĞÜ}

İnsanın doğayı tüketmesinin işlendiği yedinci bölüm Vahşi Atlar, eko-kritik bağlamda incelenebilecek bir bölümdür. İvan, adaya nereden ve nasıl geldikleri belirsiz olan bu vahşi at sürüsünün insanların saldırısına ya da köleleştirmesine maruz kalmamasına hayret eder:

İlkinden daha hayret verici ikinci bir husussa insanların atlara ilişmemesi, kimsenin gelip onları yakalayarak malına mülküne katmamasıydı. Dünyada her şey çoktan paylaşılmış, istimlak edilmiş, alım satım ya da en azından insanların istifadesi için tasnif edilmiş. Bu kıymetli ve pahalı hayvanlar insanların tamahkâr yasalarının dışında nasıl kalmışlar? Nasıl olur da kimse sahiplenmemiş onları? Nasıl olur da en güçlünün, muktedirin, mülk sahiplerinin malı olmamışlar? (Selimović, 2020, s. 59-60).

İvan'ın atların adadaki varlı̆̆ına ve evrende gerçekten özgür olduklarına dair inancı, katırcıların tüm atları yakalamasıyla yıkılır. İvan, atların tutsak edilmesini uzaktan izler ve onların ayrı hareket etmektense grup halinde beraber kalmalarının onları daha kolay av haline getirdiğini dehşetle görür:

Bu elli güzel varlıktan hiçbiri kendini düşünmüyordu ve kendi başına da değildi. Sürü lideri hepsini düşünüyordu ya da hepsi aynı şekilde düşünüyordu ve sevk-i tabii ile tüm tepkilerde eşittiler. Gruba bağlılıkları dokunaklı lakin ölümcüldü. Topluluklarına öylesine alışmışlardı ki onlar için dişarıda, başka bir hayat yoktu çünkü grup dişındaki hayatın farkında değillerdi. Fakat kendilerini koruma içgüdülerinin onları farklı davranmaya sevk etmiyor oluşu tuhaftı. Belki tam da bu içgüdü onları birlikte tutuyordu. Ama insanlar bunu biliyor ve buna güveniyorlard1 (Selimović, 2020, s. 65).

Atları nasıl kontrol edeceğini bilen insanın, atlara üstünlüğü doğanın ve vahşi yaşamın esir edilmesine örnektir. Mülkiyeti ve tüketimi kendine düstur edinen insan eylemlerini de bu maddi değerler üzerinde kurgular. Katarina, romanın en başında insanlığa inancının kalmadığını bu nedenle Tanrı'ya sığındığını söylediğinde İvan, ona bunun saçma olduğunu söylemişti. Ancak atların kementlerle yakalanıp sucuk yapılacakları İtalya'ya nakliyesi ve yeryüzünde tek özgürlük köşesi olarak yorumladığı yerin insan istilasından nasibini alması İvan'ı yaralar. Atların belediyeye ait mülk olduklarını öğrenmesi de İvan'ın tüm ümitlerini yıkar:

Vidovo Dağı'ndaki bu özgür hayat sadece bir illüzyon çünkü burası bir hapishane. Tıpkı gözle görülebilen çitleri, tel örgüleri ve gardiyanı olmayan büyük bir kümes gibi. Özgürlük ise sadece bir yem ve yanılgı. Aslında atların gidebilecek bir yerleri yok. Deniz suyu, onların seçme hürriyetinin aşılmaz sınırını oluşturuyor. İnsanlar her yıl bir defa onları fena bir şekilde korkutuyor ve bu tecrübeleri onlarda insan korkusu olarak kalıyor. Bu nedenle bu 1ssız yere bağlllık, olabilecek en güvenli duvar haline geliyor! Bu nedenle de atların hürriyete ve birlikteliğe olan aşkları, insanların en büyük yardımcısı mesabesinde. Şu hâlde bu av hince, rezil bir kandırmaca (Selimović, 2020, s. 67). 
Atların, insanın tüketim gayesine yönelik adadan götürülmeleri ve metalaştırılmaları insanın antroposentrik doğa yaklaşımını gösterir. Modern çă̆, aklın kendi yaratmadığı şeylere düşman olup, onları denetleme ve kendine bağımlı hale getirme süreci olduğundan denetlenemeyene tahammülü yoktur (Tufan, 1994, s. 69). Bu nedenle atların adadaki özgür hayatı insanın onu kendi tüketim pratiklerine göre yeniden şekillendirmesiyle sona ermiştir. Atların, kendilerinden üstün olan türe boyun eğmesi ve doğadan koparılışı doğayı sömürmeye bir girizgâhtır aslında. İvan da bu sömürünün bilincindedir ama gücü yetmediği için özgürlüğü de tıpkı hatıraları gibi belleğinde yanılsama olarak yorumlar.

Doğada güçlü olanın, güçsüz olanı kolaylıkla saf dışı bıraktığı atlar örneğini Yaşlı Köpek adlı on altıncı bölümde de görürüz. Katarina'nın bahçelerine sığınan, ölmek üzere olan bir köpeği beslemesi İvan'ın hoşuna gitmez. Ona bir zararı olmamasına rağmen, köpeği kandırarak ıssız bir yere götürür ve orada terk eder. Kancık diye hor gördüğü köpeği terk ettikten sonra biraz vicdan azabı çeker. Aslında İvan'ın köpeği terk etmesinin sebebi, onun bitkin ve ölümü hatırlatan haline katlanamamasındandır. Dolaylı da olsa köpeğin ölümüne sebep olacağı hissi onu rahatsız etse de eylemini meşrulaştırır:

Bu muhtemel ölüm, birçok sebebin sonucu olurdu. Onun yaptığı ise bu sebepler arasında dolaylı ölçüde kalırdı ve bu nedenle günah onun hanesine yazılamazdı. Gözümüzden ırak olan ızdırap canımızı yakmıyor. “Dünyada çok acı var, insanlar arasında da acı çok ve bunlar hepsine üzülmeye kalkılamayacak kadar fazla." (Selimović, 2020, s. 169).

İvan böyle düşünerek eylemini meşrulaştırır ancak atları mülkü olarak gören ve onlar üzerinde hak iddia eden katırcılardan farkı kalmaz. Çünkü o da köpeğe kaba kuvvet kullanmış ve kendi halinde bir canlıyı evinin yakınında görmeye katlanamadığı için terk etmiştir. Köpeğin birkaç gün sonra eve dönmesi İvan'ın vicdanını rahatlatır. Köpeğin, acılar içinde kıvranarak ve uluyarak ölmesi ise İvan'a sonsuz yok oluş karşısında çaresiz olduğunu hatırlatır. Köpeğin cesedini okşaması adeta ondan af dilemek için yapılan bir eylemdir.

\section{SONUÇ}

Balkanlar'ın çok kültürlü ve etnisiteli sosyal yapısını, ulus-devletlere bölünme sancısı çeken coğrafyayı topografik özellikleriyle kullanan Selimović, Ada romanında Adriyatik Denizi'nde bir adaya yerleşen yaşlı çift İvan ve Katarina Mariç'in birbirleriyle, çocuklarıyla, komşularıyla, diğer canlı türleriyle ve dünyayla kurdukları ilişkiyi insanın evrensel meseleleri üzerinden anlatmıştır. Edebiyatta önemli bir metafor olan ada, Selimović'in bu romanında merkezdedir. Hızla modernleşen bir dünyada, insanların geleneksel aile değerlerinden, akraba ve komşular gibi yakın sosyal çevrelerinden koparak bireyleşmeleri ve bu bireysellik neticesinde kendi içsel adalarına çekilerek, diğerlerinin yaşamına kayıtsız kalmaları bu romanın temalarıdır. 1950'lerin Yugoslavya'sında geçim sıkıntısı çektikleri için sade, mülksüz ve meşakkatli bir yaşam süren İvan ve Katarina şehirden adaya kendi istekleriyle göç etmiştir, çünkü şehir yaşlı insanların baş edemeyeceği kadar hızlı ve çetrefillidir. Selimović, şehirdeki zaman ve mekân sıkışmasını, Tanrı'nın modern yaşamdan sıyrılmasını, modern insanın içindeki boşluğu, tabiat katliamını, televizyonun modern bir iletişim aracı olarak, dışarıdaki dünyanın kaosunu evlere taşımasını, aklın ve mantığın gündelik hayata hükmetmesini, cinselliğin sevgiden yoksun bir göreve 
dönüşmesini ve en nihayetinde insanın hem kendisini hem de çevresini geri dönüşü imkânsız şekilde tüketmesini karakterler arasındaki kısa diyaloglar, kesik cümleler, monologlar, iç sesler ve boşluklarla anlatmıştır.

Çalışmamın başında belirttiğim amaç doğrultusunda, üç alt başlıkta incelediğim, Türkçeye kısa bir süre önce kazandırılan eseri modern yaşam kritiği şeklinde değerlendirerek modernitenin Balkan coğrafyasından bir kente ve adaya izdüşümünü özellikle sosyologların ve psikiyatristlerin birincil kaynaklarından faydalanarak gösterdim.

\section{KAYNAKÇA}

Baudrillard, Jean (2018). Tüketim Toplumu. (Çev. Ferda Keskin ve Nilgün Tutal). İstanbul: Ayrıntı Yayınları.

Bauman, Zygmunt (2018a). Ölümlülük, Ölümsüzlük ve Diğer Hayat Stratejileri. (Çev. Nurgül Demirdöven). İstanbul: Ayrıntı Yayınları.

Bauman, Zygmunt (2018b). Parçalanmış Hayat. (Çev. İsmail Türkmen). İstanbul: Ayrıntı Yayınları. Bauman, Zygmunt (2019). Akışkan Aşk. (Çev. Işıl Ergüden). İstanbul: Alfa Yayıncılık.

Csikszentmihalyi, Mihalyi. (2020). Mutluluk Bilimi: Akış (Çev. Barış Satılmış). Ankara: Buzdağı Yayınevi.

Frankl, Viktor (2019). Duyulmayan Anlam Çığhl̆ğı, Psikoterapi ve Hümanizm. (Çev. Selçuk Budak). İstanbul: Totem Yayınları.

Frankl, Viktor (2021). İnsanın Anlam Arayışı. (Çev. Selçuk Budak). İstanbul: Okuyan Us Yayınevi.

Geçtan, Engin (2016). Varoluş ve Psikiyatri. İstanbul: Metis Yayınları.

Geçtan, Engin (2018). Rastgele Ben. İstanbul: Metis Yayınları.

Giddens, Anthony (2019). Modernite ve Bireysel Kimlik: Geç Modern Çă̆da Benlik ve Toplum. (Çev. Ümit Tatlıcan). İstanbul: Say Yayınları.

Goffman, Erving (2021). Kamusal Alanda İlişkiler: Toplu Yaşamın Mikro Incelemeleri. (Çev. M. Fatih Karakaya). Ankara: Heretik Yayınları.

Harvey, David (2015). Asi Şehirler. (Çev. Ayşe Deniz Temiz). İstanbul: Metis Yayınları.

Harvey, David (2019). Postmodernliğin Durumu. (Çev. Sungur Savran). İstanbul: Metis Yayınları.

Hayden, R. M. (2007). Moral Vision and Impaired Insight, The Imagining of Other People's Communities in Bosnia. Current Anthropology, 48(1), 105-131.

İnalhan, Göksenin. (2020). İnsan-Mekân-Zaman: Yerinde Yaşlanma ve Sağl1k-Herkes için Yaşanabilir Kent. Cogito 98(1), 153-164. İstanbul: Yapı Kredi Yayınları.

Krishnamurti, Jiddu. (2013). İlk ve Son Özgürlük. (Çev. Ayşegül Korkmaz). İstanbul: Omega Yayınları.

May, Rollo. (2021). Kendini Arayan İnsan. (Çev. Kerem Işı). İstanbul: Okuyan Us Yayınevi.

Phillips, Adam. (2019). Kaçırdıklarımız: Yaşanmamış Hayata Övgü. (Çev. Selin Siral). İstanbul: Metis Yayınları.

Selimović, Meša. (2020). Ada. (Çev. Azra Blekiç Aydoğan ve İbrahim Hakan Aydoğan). İstanbul: Ketebe Yayınları.

Tillich, Paul. (2020). Olmak Cesareti. (Çev. F. Cihan Dansuk). İstanbul: Okuyan Us Yayınevi. 
Tufan, H. (2018). Kolektif Bellek ve İnsan/Doğa İlişkisi. Cogito, 2(5), 69-73. İstanbul: Yapı Kredi Yayınları.

Turner, Bryan. S. (2017). Tıbbi Güç ve Toplumsal Bilgi. (Çev. Ümit Tatlıcan). İstanbul: Sentez Yayincilik.

Wachtel, Andrew. (2006). The Legacy of Danilo Kić in Post-Yugoslav Literature. The Slavic and East European Journal 50 (1), 135-149.

Britannica, T. Editors of Encyclopaedia (b.t). Ustaša. Encyclopedia Britannica. https://www.britannica.com/topic/Ustasa (erişim 15.11.2021) 


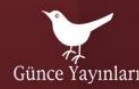

Prof. Dr. Önder Göçgün

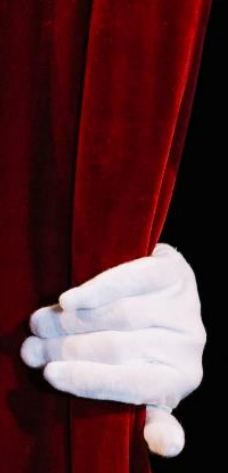

TIYYATRO DENEN HAYAT

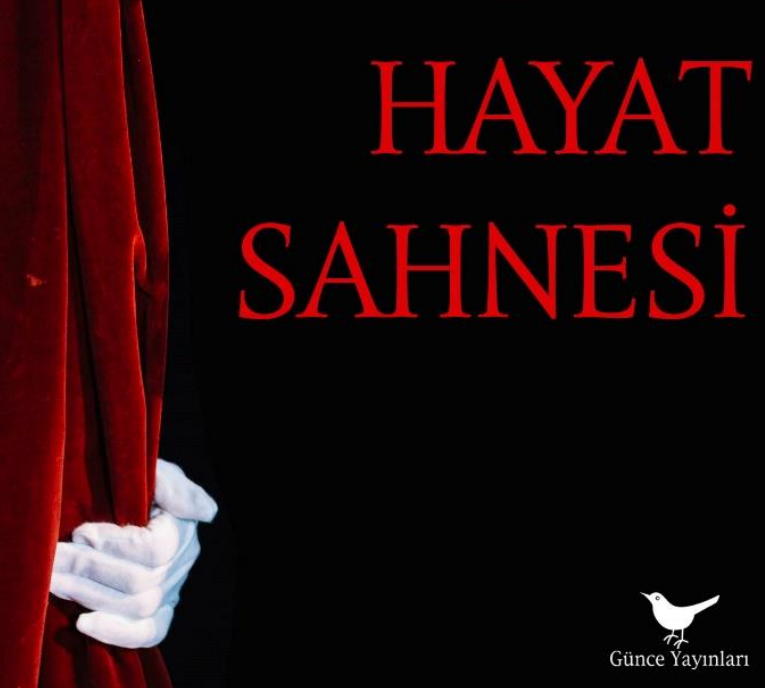

MUIIARREM DAYANC OKTAY YIVLI MACI'I BALIK MAIIMU'I BABACAN SLVIM SLERMEI
YASFMIN MUMCU BLDI் KOÇАKOĞLU NILÜLLLR ILLHAN MAKSUT YIĞITBAS SLL $\triangle M I I L \Lambda N$

\section{EDEBIYATINDA

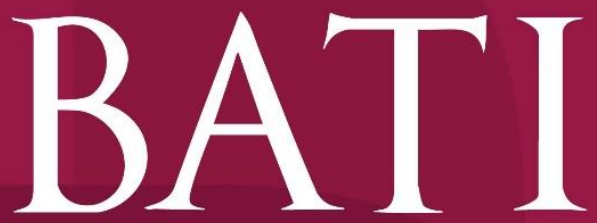 \\ EDEBIYATINDA
AKIMLAR \\ $\underset{\substack{\text { EDEBIYATINDA } \\ \text { AKIMLAR }}}{\mathrm{B} A T \mathrm{~T}}$}

editör

OKTAY YIVLI

HATICE FIRAT

YASEMIN MUMCU

OKTAY YIVLI

OĞUZHAN KARABURGU

BERNA AKYÜZ SIZGEN

NILÜFER ILHAN
ÜMMÜHAN TOPÇU

SEFA YÜCE

HANIFI ASLAN

METIN AKYÜZ

MEHMET SÜMER
YAKUP ÖZTÜRK
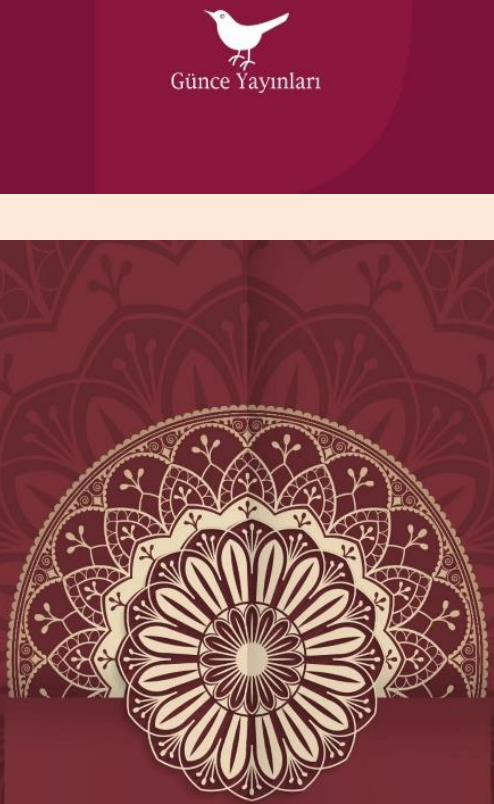

PROF. DR. ÖNDER GÖÇGÜN

$$
\begin{gathered}
\text { Türk } \\
\text { Tasavvuf } \\
\text { Siini }
\end{gathered}
$$

AÇIKLAMALI VE YORUMLU ÖRNEKLERLE 